\title{
Catalytic asymmetric construction of spiro pyrrolidines with contiguous quaternary centers via 1,3-dipolar cycloaddition of azomethine ylides
}

\author{
Tanglin Liu a , Qinghua Li a , Zhaolin Hea, Jiawei Zhang a, Chunjiang Wang a,b,* \\ a College of Chemistry and Molecular Sciences, Wuhan University, Wuhan 430072, Hubei, China \\ bState Key Laboratory of Organometallic Chemistry, Shanghai Institute of Organic Chemistry, Chinese Academy of Sciences, Shanghai 230032, China
}

\section{A R T I C L E I N F}

Article history:

Received 26 June 2014

Accepted 22 July 2014

Published 20 January 2015

\section{Keywords:}

Asymmetric catalysis

Quaternary stereogenic center

1,3-Dipolar cycloaddition

Azomethine ylide

Cyclopropylidene acetate

5-Aza-spiro[2,4]heptane

\begin{abstract}
A B S T R A C T
Bioactive 5-aza-spiro[2,4]heptanes with high functionality and up to three contiguous all-carbon quaternary stereogenic centers were synthesized by $\mathrm{Cu}(\mathrm{I})$-catalyzed asymmetric endo-selective 1,3-dipolar cycloaddition of azomethine ylides with cyclopropylidene acetates. This synthesis system performs well for a broad scope of substrates. $\alpha$-unsubstituted $/ \alpha$-substituted azomethine ylides and cyclopropylidene acetates are compatible 1,3-dipoles and dipolarophiles, which afford the spiro heterocycles with contiguous quaternary centers at 2-, 3- and 4-positions of the pyrrolidine ring in good yield (up to 97\%) and high diastereoselectivity (95:5->98:2 d.r) and excellent enantioselectivity (87\%-98\% ee).
\end{abstract}

(C) 2015, Dalian Institute of Chemical Physics, Chinese Academy of Sciences. Published by Elsevier B.V. All rights reserved.

allylation [13], Pd-catalyzed asymmteric [3+2] annulation of 5-vinyloxazolizinones with trisubstituted alkenes [14], sequential Michael reactions [15] and alkylation of 3-bromooxinodoles with 3-substituted indoles [16].

Nitrogen heterocyclic pyrrolidines are key structural motifs frequently present in biological compounds and building blocks that occupy a privileged position in organic synthesis $[17,18]$. Moreover, pyrrolidine derivatives have also been utilized as organocatalysts in recent years [19-21]. The general strategy for constructing five-membered heterocycles was the cycloaddition reaction of various 1,3-dipoles with electron-deficient alkenes or alkynes as the dipolarophiles [22-27]. Although

\footnotetext{
* Corresponding author. Fax: +86-27-68754067; E-mail: cjwang@whu.edu.cn

This work was supported by the National Basic Research Program of China (973 Program, 2011CB808600), the National Natural Science Foundation of China (21172176, 21372180), Hubei Province Natural Science Foundation (ZRZ0273), Fundamental Research Funds for the Central Universities, and an Academic Award for Excellent PhD Candidates Funded by the Ministry of Education of China (5052011203011).

DOI: 10.1016/S1872-2067(14)60204-7 | http://www.sciencedirect.com/science/journal/18722067 | Chin. J. Catal., Vol. 36, No. 1, January 2015
} 
metal-stabilized azomethine ylides have been employed as readily available 1,3-dipole in the chiral-auxiliary-induced asymmetric 1,3-dipolar cycloaddition for the construction of enantiomerically enriched pyrrolidines [28-37], the first catalytic asymmetric variant of the 1,3-dipolar cycloaddition reaction of azomethine ylides was reported by Zhang's group [38] using a $\mathrm{Ag}(\mathrm{I}) / x y l y l-F A P$ complex and Jörgensen's group [39] using a $\mathrm{Zn}$ (II)/bisoxazoline complex only in 2002. Since then, enormous efforts have been made on the development of catalytic stereoselective 1,3-dipolar cycloaddition of azomethine ylides with electron-deficient olefins to give a variety of highly functionalized pyrrolidines with multiple stereogenic centers [40-55]. The construction of quaternary, especially spiro quaternary, stereogenic centers has also been developed [56-61]. Most recently, the catalytic asymmetric 1,3-dipolar cycloaddition reactions of azomethine ylides with trisubstituted electron-deficient alkenes for the construction of spiro[oxindolepyrrolidine]s were developed by Gong's group [62-64], Waldmann's group [65,66], Arai's group [67], Wang's group [68,69] and our group [70-74]. However, the synthesis of chiral sprio pyrrolidine heterocycles with vicinal quaternary stereogenic centers by 1,3-dipolar cycloaddition of azomethine ylides has been seldom reported.

Cyclopropane structures are common components in many natural products such as terpenoids and steroids exhibiting significant biological activity [75-77]. Methylenecyclopropanes (MCPs) have been well documented as important synthetic intermediates in organic synthetic chemistry in the past three decades [78,79], and MCPs were used as a three-carbon unit dipole in a variety of the transition metal-catalyzed ring-opening processes $[80,81]$ due to the potent thermodynamic driving force rendered by the relief of the 3-membered ring strain. Examples on ring-untouched transformations employing MCP derivatives as dipolarophiles [82] have also been reported in 1,3-dipolar cycloaddition reactions, in which nitrones, nitrile oxides, azides, diazoalkanes, nitrile ylides and oximes were employed as the corresponding 1,3-dipoles.

In a previous communication, we developed a highly efficient $\mathrm{Cu}(\mathrm{I}) / \mathrm{TF}$-BiphamPhos-catalyzed asymmetric 1,3-dipolar cycloaddition of azomethine ylides with ethyl cyclopropylidene acetates leading to the synthesis of spiro [cyclopropan-3,3'pyrrolidine] with excellent endo-selectivity and enantioselectivity (Table 1) [71]. The spiro[cyclopropan-3,3'-pyrrolidine], that is, 5-aza-spiro[2,4]heptane, structure motif with a spiro carbon connecting two key units of cyclopropane and pyrrolidine plays an important role in the structure-activity relationship of many antibacterial agents. The unique 5-aza-spiro[2,4] heptane scaffold can remarkably enhance the carbapenems analogs, substituted oxazolidinones and quinolone antibiotics, especially against both gram-positive and gram-negative bacteria [83-89].

As part of our continuing efforts in this area, here we report a full account of the catalytic asymmetric synthesis of diversified 5-aza-spiro[2,4]heptanes with high functionalities and three stereogenic centers including up to three contiguous all-carbon quaternary centers by $\mathrm{Cu}(\mathrm{I}) / \mathrm{TF}-$ BiphamPhos-catalyzed 1,3-dipolar cycloaddition of azomethine ylides derived
Table 1

Asymmetric 1,3-dipolar cycloaddition of various glycinate-derived imino esters $\mathbf{2}$ with ethyl cyclopropylidene acetate $\mathbf{1 a}$ for the synthesis of 5-aza-spiro[2,4]heptanes.

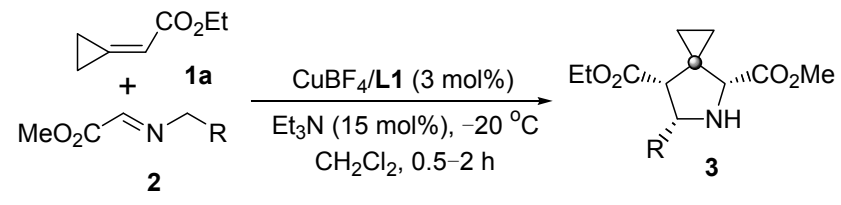

\begin{tabular}{|c|c|c|c|c|c|}
\hline Entry & $\mathrm{R}(2)$ & 3 & Yield $^{\mathrm{a}}(\%)$ & endo:exo ${ }^{\mathrm{b}}$ & $\mathrm{ee}^{\mathrm{b}}(\%)$ \\
\hline 1 & $p-\mathrm{Cl}-\mathrm{C}_{6} \mathrm{H}_{4}(\mathbf{2 a})$ & 3aa & 90 & $>98: 2$ & 98 \\
\hline 2 & $o-\mathrm{Cl}-\mathrm{C}_{6} \mathrm{H}_{4}(\mathbf{2 b})$ & $3 a b$ & 97 & $97: 3$ & 97 \\
\hline 3 & $p-\mathrm{Br}-\mathrm{C}_{6} \mathrm{H}_{4}(2 \mathrm{c})$ & 3ac & 87 & $95: 5$ & 98 \\
\hline 4 & $p-\mathrm{F}-\mathrm{C}_{6} \mathrm{H}_{4}(\mathbf{2 d})$ & 3ad & 85 & $97: 3$ & 97 \\
\hline 5 & $\mathrm{Ph}(2 \mathbf{e})$ & 3ae & 81 & $95: 5$ & 95 \\
\hline 6 & $p-\mathrm{Me}-\mathrm{C}_{6} \mathrm{H}_{4}(\mathbf{2 f})$ & 3af & 78 & $96: 4$ & 97 \\
\hline 7 & $m-\mathrm{Me}-\mathrm{C}_{6} \mathrm{H}_{4}(\mathbf{2 g})$ & 3ag & 90 & $>98: 2$ & 98 \\
\hline 8 & $o-\mathrm{Me}-\mathrm{C}_{6} \mathrm{H}_{4}(\mathbf{2 h})$ & 3ah & 87 & $>98: 2$ & 96 \\
\hline 9 & $p-\mathrm{MeO}-\mathrm{C}_{6} \mathrm{H}_{4}(2 \mathbf{i})$ & 3ai & 78 & $>98: 2$ & 98 \\
\hline 10 & 1-Naphthyl (2j) & 3aj & 82 & $>98: 2$ & 92 \\
\hline 11 & 2-thienyl (2k) & 3ak & 89 & $>98: 2$ & 94 \\
\hline $12^{\mathrm{c}}$ & cinnamyl (2l) & 3al & 76 & $>98: 2$ & 93 \\
\hline
\end{tabular}

All reactions were carried out with $0.20 \mathrm{mmol}$ of $1 \mathrm{a}$ and $0.40 \mathrm{mmol}$ of 2 in $2 \mathrm{~mL}$ of $\mathrm{CH}_{2} \mathrm{Cl}_{2} . \mathrm{CuBF}_{4}=\mathrm{Cu}\left(\mathrm{CH}_{3} \mathrm{CN}\right)_{4} \mathrm{BF}_{4}$.

a Isolated yield.

b Enantiomeric excesses and diastereomeric ratio were determined by chiral HPLC analysis. Minor exo-isomer was not detected on the crude ${ }^{1} \mathrm{H}$ NMR

c Reaction was carried out at $0^{\circ} \mathrm{C}$ in $1 \mathrm{~h}$.

from both $\alpha$-unsubstituted and $\alpha$-substituted $\alpha$-amino acid with a variety of $\alpha$-substituted cyclopropylidene acetates (Scheme 1).

\section{Experimental}

General procedure for the asymmetric 1,3-dipolar cycloaddition of azomethine ylides with ethyl cyclopropylidene acetates catalyzed by $\mathrm{Cu}\left(\mathrm{CHC}_{3} \mathrm{CN}\right)_{4} \mathrm{BF}_{4} /(S)$-TF-BiphamPhos complex. Under an argon atmosphere, $(S)$-TF-BiphamPhos $(0.0072$ mmol) and $\mathrm{Cu}\left(\mathrm{CHC}_{3} \mathrm{CN}\right)_{4} \mathrm{BF}_{4}(2.0 \mathrm{mg}, 0.006 \mathrm{mmol})$ were dissolved in $2 \mathrm{~mL} \mathrm{CH}_{2} \mathrm{Cl}_{2}$ and stirred at room temperature for $1 \mathrm{~h}$. Then, the imine substrate $(0.4 \mathrm{mmol}), \mathrm{Et}_{3} \mathrm{~N}(0.03 \mathrm{mmol})$, and ethyl cyclopropylidene acetates $(0.2 \mathrm{mmol})$ were added sequentially. Once the starting material was consumed (monitored by TLC), the mixture was filtered through celite and the filtrate was concentrated to dryness. The product was purified by column chromatography to give the corresponding cycloaddition product, which was then directly analyzed by chiral HPLC to determine the enantiomeric excess.

\section{Results and discussion}

\subsection{Cu(I)-catalyzed 1,3-dipolar cycloaddition of $\alpha$-substituted azomethine ylides with ethyl cyclopropylidene acetates}

Encouraged by the excellent results achieved with $\alpha$-unsubstituted azomethine ylides derived from glycinate in our previous communication [71], we further investigated the possibility of employing $\alpha$-substituted imino esters as the di- 


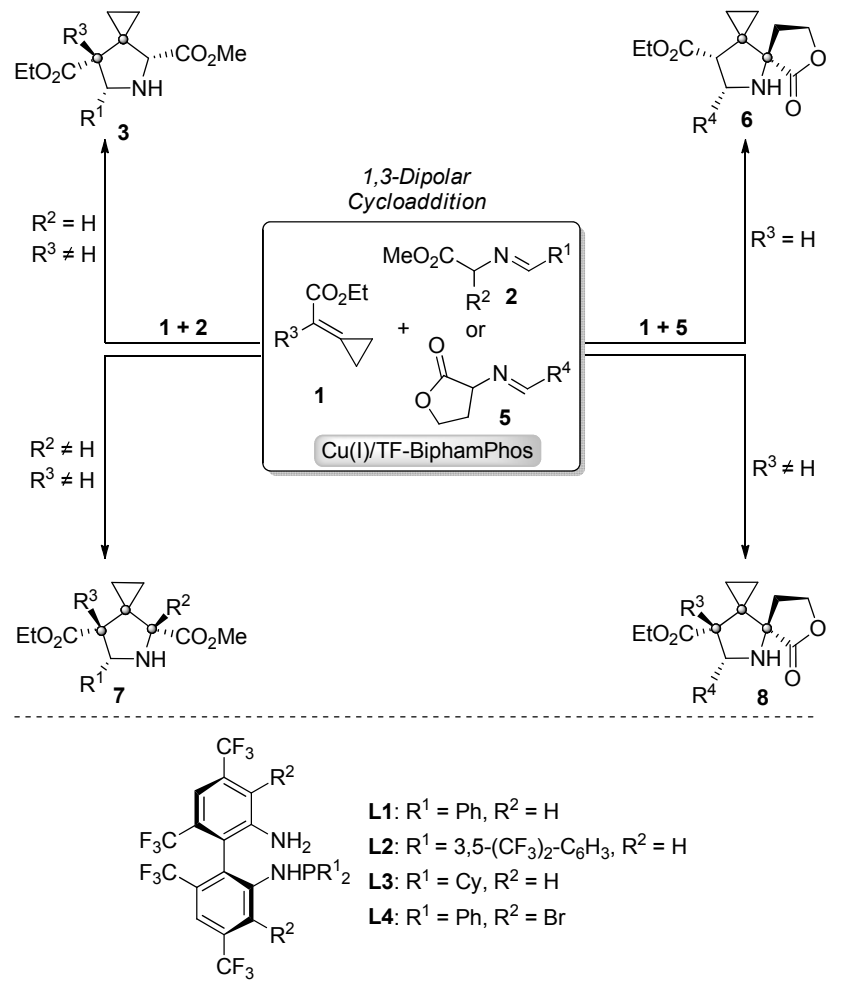

(S)-TF-BiphamPhos

Scheme 1. Construction of spiro pyrrolidine heterocycles with contiguous quaternary centers via $\mathrm{Cu}(\mathrm{I})$-catalyzed 1,3-dipolar cycloaddition of azomethine ylides with cyclopropylidene acetates.

pole precursors. These are challenging substrates due to the unfavourable steric hindrance because two contiguous quaternary centers can be formed and the lower acidity of the corresponding methene $\mathrm{CH}$ group between the imine and ester. Hence, although the generated pyrrolidines containing a unique quaternary stereogenic center are of great importance and synthetic potential, $\alpha$-substituted imino esters have been seldom employed in the asymmetric 1,3-dipolar cycloaddition compared with $\alpha$-unsubstituted imino esters derived from glycinate. To our delight, under the optimal conditions in the previous communication, various imino esters derived from $\alpha$-substituted amino acid, such as $( \pm)$-alanine, ( \pm )-leucine, $( \pm)$-2-aminobutyric acid and ( \pm )-phenylalanine were tolerated in this catalytic system, which provided the corresponding highly functionalized pyrrolidines containing a unique nitrogen-substituted quaternary stereogenic center adjacent to the spiro quaternary carbon center in exclusive diastereoselectivities and excellent enantioselectivities (Table 2).

\subsection{Cu(I)/TF-BiphamPhos-catalyzed 1,3-dipolar cycloaddition of azomethine ylides with $\alpha$-substituted ethyl 2-cyclopropylidene acetates}

To better define the substrate scope with respect to the dipolarophiles, the more sterically hindered $\alpha$-substituted ethyl 2-cyclopropylidene acetates were employed. Spiro[cyclopropan-3,3'-pyrrolidine] with two adjacent quaternary centers at
Table 2

Asymmetric 1,3-dipolar cycloaddition of $\alpha$-substituted imino esters 2 with ethyl 2-cyclopropylidene acetate $\mathbf{1 a}$.

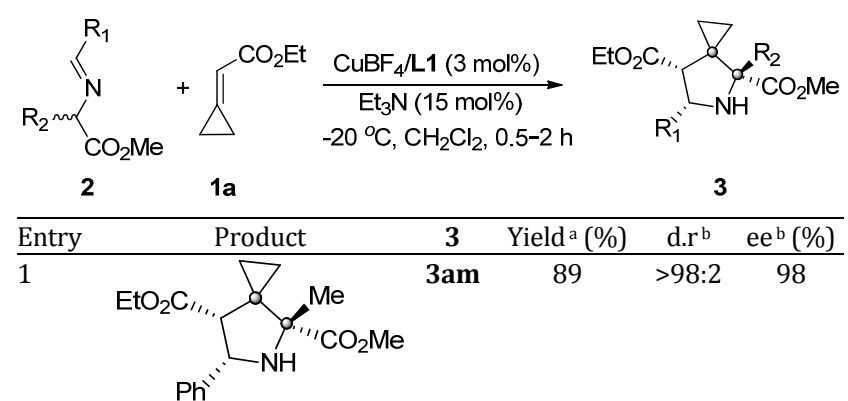

2

3

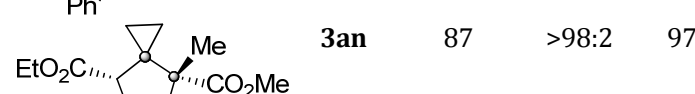

4

$p-\mathrm{Cl}_{-} \mathrm{C}_{6} \mathrm{H}_{4}$

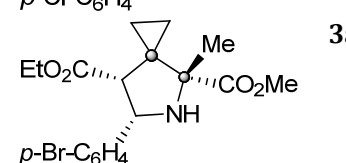

$p-\mathrm{Br}_{-} \mathrm{C}_{6} \mathrm{H}_{4}$

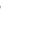

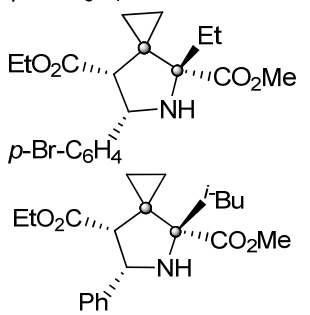

6

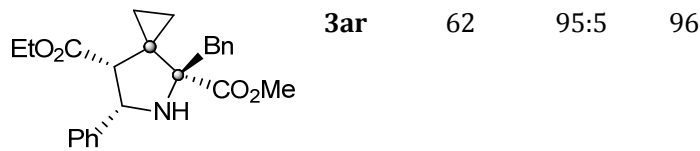

All reactions were carried out with $0.20 \mathrm{mmol}$ of $1 \mathrm{a}$ and $0.40 \mathrm{mmol}$ of 2 in $2 \mathrm{~mL}$ of $\mathrm{CH}_{2} \mathrm{Cl}_{2}, \mathrm{CuBF}_{4}=\mathrm{Cu}\left(\mathrm{CH}_{3} \mathrm{CN}\right)_{4} \mathrm{BF}_{4}$.

a Isolated yield.

${ }^{b}$ Enantiomeric excesses and diastereomeric ratios were determined by chiral HPLC analysis. Minor exo-isomer was not detected on the crude ${ }^{1} \mathrm{H}$ NMR.

the 3 and 7 positions of the spiro pyrrolidine rings were expected. Under the optimal reaction conditions, we successfully extended the dipolarophile scope to various $\alpha$-substituted 2-cyclopropylidene acetates. As shown in Table 3, ethyl 2-cyclopropylidene acetates bearing alkyl substitutes such as methyl (1b, entry 1), ethyl (1c, entry 2), $n$-propyl (1d, entry 3 ), and benzyl (1e, entry 4), and aromatic ring substitutes such as phenyl (1f, entry 5) groups at the $\alpha$ position of the ester group were all proven compatible in this annulation process with azomethine ylide 2a, smoothly affording the corresponding spiro cycloadducts exclusively in good yields and excellent diastereoselectivities and high enantioselectivities (up to $>98: 2$ d.r, and $92 \%-96 \%$ ee). This is the first example of the $\alpha, \alpha, \beta, \beta$-tetrasubstituted electron-deficient alkenes used as the dipolarophiles in the catalytic asymmetric 1,3-dipolar cycloaddition. The absolute configuration of spiro pyrrolidine 3ca was determined as $(4 R, 6 R, 7 R)$ by X-ray analysis of its corresponding $N$-tosylated derivative 4 (Fig. 1. CCDC 962660 (4) contains the supplementary crystallographic data for this paper). 
Table 3

Asymmetric 1,3-dipolar cycloaddition of $\mathbf{2 a}$ with various of $\alpha$-substituted ethyl 2-cyclopropylidene acetates $\mathbf{1}$.

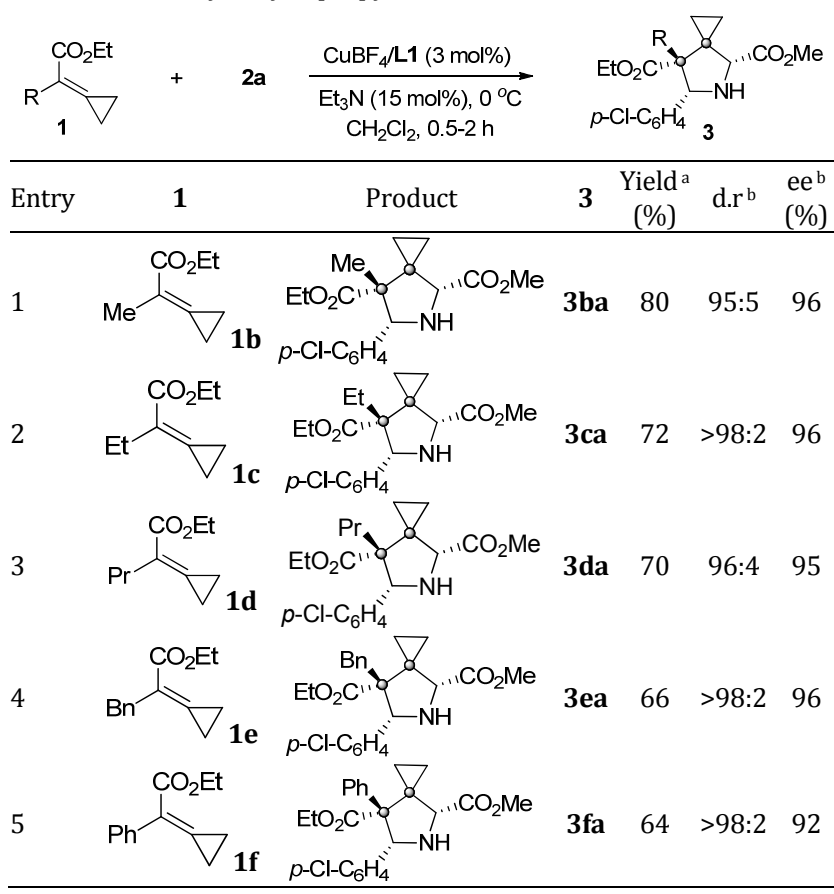

All reactions were carried out with $0.20 \mathrm{mmol}$ of $\mathbf{1}$ and $0.40 \mathrm{mmol}$ of $\mathbf{2 a}$ in $2 \mathrm{~mL}$ of $\mathrm{CH}_{2} \mathrm{Cl}_{2}, \mathrm{CuBF}_{4}=\mathrm{Cu}\left(\mathrm{CH}_{3} \mathrm{CN}\right)_{4} \mathrm{BF}_{4}$.

a Isolated yield.

b Enantiomeric excesses and diastereomeric ratios were determined by chiral HPLC analysis. The minor exo-isomer was not detected in the crude ${ }^{1} \mathrm{H}$ NMR.

\section{3. $\mathrm{Cu}(\mathrm{I}) /$ TF-BiphamPhos-catalyzed 1,3-dipolar cycloaddition} of homoserine lactone derived cyclic azomethine ylides with ethyl 2-cyclopropylidene acetate

To further probe the applicability of this 1,3-dipolar cycloaddition reaction to construct the more complex spiro[cyclopropan-3,3'-pyrrolidine], we turned our attention to the cyclic azomethine ylides derived from homoserine lactones. A tricyclic spiro heterocycle bearing one cyclopropane, one pyrrolidine and one butylactone moiety would be expected along with two generated quaternary centers in this transformation. When the cyclic imino ester 5e reacted with ethyl 2-cyclopropylidene acetate $1 \mathrm{a}$ in the presence of $3 \mathrm{~mol} \%$ of $\mathrm{Cu}\left(\mathrm{CH}_{3} \mathrm{CN}\right)_{4} \mathrm{BF}_{4} /(S)$-TF-BiphamPhos (L1) and $15 \mathrm{~mol} \% \mathrm{Et}_{3} \mathrm{~N}$ in $\mathrm{CH}_{2} \mathrm{Cl}_{2}$ at room temperature, the designed product was obtained with a moderate yield although only with $82 \%$ ee (Table 4 , entry 1). Thus, the reaction conditions were re-optimized to improve the asymmetric induction efficiency. Having screened the reaction parameters including the metal source, chiral ligand and reaction temperature, it was elucidated that the best result in terms of both the yield and enantioselectivity was achieved when the reaction was catalyzed by the complex of $\mathrm{Cu}\left(\mathrm{CH}_{3} \mathrm{CN}\right)_{4} \mathrm{BF}_{4}$ and chiral $\mathbf{L 4}$ at room temperature (Table 4, entry 5).

The substrate scope and limitation of the cyclic imino esters in this annulation was further extended under the re-optimized reaction condition. The results are listed in Table 5. In general,
Table 4

Optimization of the reaction conditions for cyclo imino esters $\mathbf{5}$.

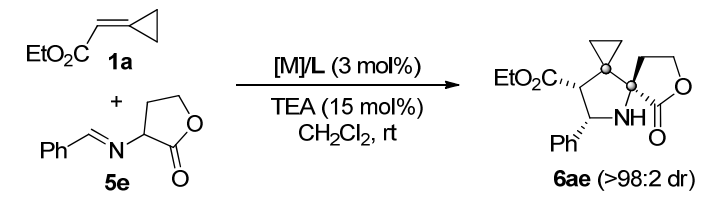

\begin{tabular}{lcccc}
\hline Entry & {$[\mathrm{M}]$} & L & Yield $^{\mathrm{a}}(\%)$ & ee $^{\mathrm{b}}(\%)$ \\
\hline 1 & $\mathrm{Cu}\left(\mathrm{CH}_{3} \mathrm{CN}\right)_{4} \mathrm{BF}_{4}$ & $\mathbf{L 1}$ & 55 & 82 \\
2 & $\mathrm{AgOAc}$ & $\mathbf{L 1}$ & 25 & 31 \\
3 & $\mathrm{Cu}\left(\mathrm{CH}_{3} \mathrm{CN}\right)_{4} \mathrm{BF}_{4}$ & $\mathbf{L 2}$ & 25 & 31 \\
4 & $\mathrm{Cu}\left(\mathrm{CH}_{3} \mathrm{CN}\right)_{4} \mathrm{BF}_{4}$ & $\mathbf{L 3}$ & 29 & 61 \\
5 & $\mathrm{Cu}\left(\mathrm{CH}_{3} \mathrm{CN}\right)_{4} \mathrm{BF}_{4}$ & $\mathbf{L 4}$ & 80 & 95 \\
\hline
\end{tabular}

All reactions were carried out with $0.40 \mathrm{mmol}$ of $\mathbf{5 e}$ and $0.20 \mathrm{mmol}$ of 1 a in $2 \mathrm{~mL} \mathrm{CH}_{2} \mathrm{Cl}_{2}$.

asolated yield.

${ }^{\mathrm{b}}$ Enantiomeric excesses and diastereomeric ratios were determined by chiral HPLC analysis. The minor exo-isomer was not detected on the crude ${ }^{1} \mathrm{H}$ NMR.

ethyl cyclopropylidene acetate 1a reacted with various cyclic imino esters generated from aldehydes and homoserine lactone smoothly affording the desired adducts in high yields (40\%-82\%) with exclusive diastereoselectivities (>98:2 d.r) and excellent enantioselectivities $(87 \%-96 \%$ ee $)$. The 10-position of the spiro-pyrrolidines can be substituted with arenes containing electron-withdrawing (Table 5, entries 1-4), electron-neutral (Table 5, entry 5) and electron-donating groups (Table 5, entries 6-9) as well as heterocycles such as 2 -furanyl (6ak) and 2-thienyl (6al). Cyclic imino esters derived from $\alpha$-naphthylaldehyde also worked well in this reaction, and the desired spirocyclic 6aj can be obtained in $70 \%$ yield and $90 \%$ ee (Table 5, entry 10). However, the less reactive aliphatic cyclic imino esters did not work in this cycloaddition reaction under the re-optimized reaction condition. The absolute configuration of the spiro-pyrrolidines 6ad was established by X-ray diffraction analysis (Fig. 1. CCDC 962659 (6ad) contains the supplementary crystallographic data for this paper).

\subsection{Cu(I)/TF-BiphamPhos-catalyzed 1,3-dipolar cycloaddition} of $\alpha$-substituted azomethine ylides with $\alpha$-substituted ethyl 2-cyclopropylidene acetate for the construction of spiro heterocycles with three adjacent quaternary centers

In addition, we tested the construction of spiro[cyclopropan-3,3'-pyrrolidine] bearing three adjacent quaternary centers, two of which are quaternary stereogenic centers, generated by 1,3-dipolar cycloaddition of the $\alpha$-methyl substituted azomethine ylide $\mathbf{2 n}$ or cyclic azomethine ylide $\mathbf{5 e}$ with $\alpha$-benzyl ethyl 2-cyclopropylidene acetate 1e (Scheme 2). The reactions were carried out successfully in the $\mathrm{Cu}(\mathrm{I})$-catalytic system employing chiral ligands $\mathbf{L} \mathbf{1}$ and $\mathbf{L 4}$, respectively. The target products were obtained with excellent diastereoselectivities and enantioselectivities (96\% ee for 7 and $93 \%$ ee for 8 ) although with moderate yields. This construction of chiral pyrrolidines with contiguous three quaternary centers via the 1,3-dipolar cycloaddition reaction was developed for the first time. 
Table 5

Asymmetric 1,3-dipolar cycoladdition of various cyclo imino esters 5 with cyclopropyl-ideneacetate $\mathbf{1 a}$.

12

All reactions were carried out with $0.20 \mathrm{mmol}$ of $\mathbf{1 a}$ and $0.40 \mathrm{mmol}$ of $\mathbf{5}$ in $2 \mathrm{~mL}$ of $\mathrm{CH}_{2} \mathrm{Cl}_{2}$. $\mathrm{CuBF}_{4}=\mathrm{Cu}\left(\mathrm{CH}_{3} \mathrm{CN}\right)_{4} \mathrm{BF}_{4}$.

a Isolated yield.

${ }^{b}$ Enantiomeric excesses and diastereomeric ratios were determined by chiral HPLC analysis. The minor exo-isomer was not detected in the crude ${ }^{1} \mathrm{H}$ NMR.

\subsection{Possible transition state in the Cu(I)/TF-BiphamPhos-} catalyzed 1,3-dipolar cycloaddition of azomethine ylides with cyclopropylidene acetate

Based on these results and previous DFT studies [90,91], a stepwise Michael/Mannich mechanism [92-95] can be pro-

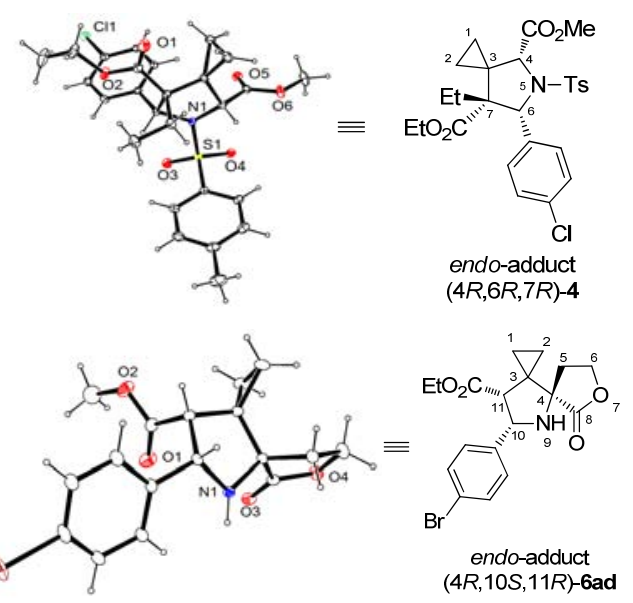

Fig. 1. The structures of $(4 R, 6 R, 7 R)-\mathbf{4}$ and $(4 R, 10 S, 11 R)-\mathbf{6 a d}$.

posed. The transition state model in Fig. 2 accounts for the observed endo-selectivity of the 1,3-dipolar cycloaddition of imino esters with ethyl 2-cyclopropylidene acetates in the presence of $\mathrm{Cu}\left(\mathrm{CH}_{3} \mathrm{CN}\right)_{4} \mathrm{BF}_{4} /(S)$-TF-BiphamPhos (L1). The in-situ formed azomethine ylide is coordinated to the metallic center and oriented as determined by the steric repulsion between the two phenyl group in the ylide and on the phosphorus atom of the chiral ligand. The dipolarophile ethyl 2-cyclopropylidene acetate $\mathbf{1}$ approaches the less-hindered face of the azomethine ylide, that is, the $S i(\mathrm{C}=\mathrm{N})$ face in this case, to avoid steric congestion, and hence form the endo-selective $(4 R, 6 S, 7 R)-5$-azaspiro[2,4]-heptane observed in the experimental results. The possible hydrogen bond interaction between the carbonyl group of the dipolarophile $\mathbf{1}$ and the $\mathrm{NH}_{2}$ group of the chiral $(S)$-TF-BiphamPhos ligand (L1) would stabilize the transition state $[96,97]$.
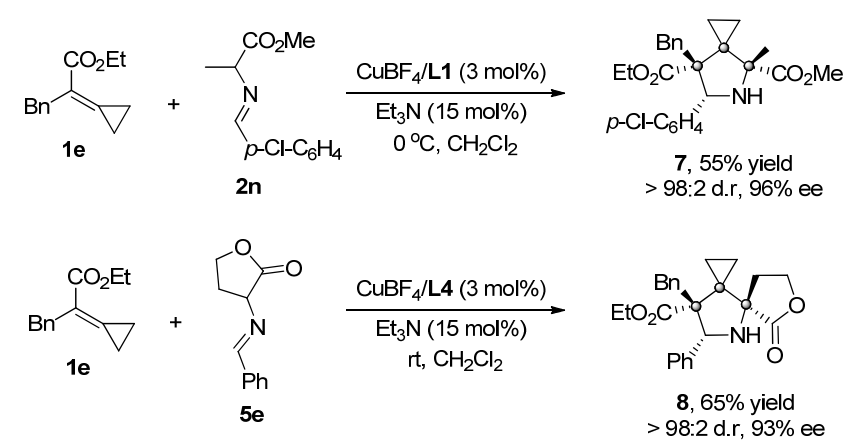

Scheme 2. 1,3-Dipolar cycloaddition of $\alpha$-substituted azomethine ylides with $\alpha$-substituted cyclopropylidene acetate $1 \mathbf{e}$ for the construction of spiro pyrrolidines with three adjacent quaternary centers.

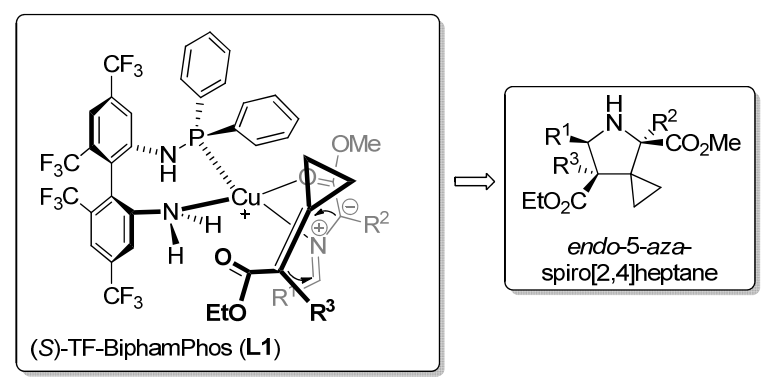

Fig. 2. Transition states leading to endo-5-aza-spiro[2,4]heptane. 


\section{Conclusions}

We have developed a general methodology for the direct and facile synthesis of various enantiomerically enriched endo-5-aza-spiro[2,4] heptane derivatives by the highly efficient $\mathrm{Cu}(\mathrm{I})$-catalyzed 1,3-dipoalr cycloaddition of a variety of $\alpha$-unsubstituted and $\alpha$-substituted azomethine ylides with various cyclopropylidene acetates. This reaction provides a convenient method to access highly substituted spiro[cyclopropan-3,3'pyrrolidine] with up to three contiguous quaternary centers in high yields and excellent diastereoselectivities (up to >98:2 dr) and enantioselectivites (up to $98 \%$ ee).

\section{Acknowledgments}

We thank Prof. Hua Li at Wuhan University for solving the crystal structure.

\section{References}

[1] Trost B M, Jiang C H. Synthesis, 2006: 369

[2] Flynn A B, Ogilvie W W. Chem Rev, 2007, 107: 4698

[3] Hawner C, Alexakis A. Chem Commun, 2010, 46: 7295

[4] Uyeda C, Rötheli A R, Jacobsen E N. Angew Chem Int Ed, 2010, 49: 9753

[5] Christoffers J, Mann A. Angew Chem Int Ed, 2001, 40: 4591

[6] Christoffers J, Baro A. Angew Chem Int Ed, 2003, 42: 1688

[7] Christoffers J, Baro A. Quaternary Stereocenters: Challenges and Solutions for Organic Synthesis. German: Wiley-VCH, 2006

[8] Peterson E A, Overman L E. Proceed Nat Acad Sci USA, 2004, 101: 11943

[9] Ardolino M T, Morken P.J Am Chem Soc, 2014, 136: 7092

[10] Cao Z Y, Wang X M, Tan C, Zhao X L, Zhou J, Ding K L. J Am Chem Soc, 2013, 135: 8197
[11] Gao L Z, Hwang G-S, Ryu D H. J Am Chem Soc, 2011, 133: 20708

[12] Trost B M, Osipov M. Angew Chem Int Ed, 2013, 52: 9176

[13] Ghosh S, Bhunia S, Kakde B N, De S, Bisai A. Chem Commun, 2014, 50: 2434

[14] Ohmatsu K, Imagawa N, Ooi T. Nat Chem, 2014, 6: 47

[15] Mitsunuma H, Shibasaki M, Kanai M, Matsunaga S. Angew Chem Int $E d, 2012,51: 5217$

[16] Zhang H L, Hong L, Kang H, Wang R. J Am Chem Soc, 2013, 135: 14098

[17] Harwood L M, Vickers R J. In: Padwa A, Peasson W H eds. Synthetic Applications of 1,3-Dipolar Cycloaddition Chemistry Toward Heterocycles and Natural Products. German: John Wiley \& Sons, 2003. 169

[18] Pyne S G, Davis A S, Gates N J, Hartley J P, Lindsay K B, Machan T, Tang M. Synlett, 2004: 2670

[19] Bolm C, Rantanen T, Schiffers I, Zani L. Angew Chem Int Ed, 2005, 44: 1758

[20] Conde E, Bello D, de Cozar A, Sanchez M, Vazquez M A, Cossio F P. Chem Sci, 2012, 3: 1486

[21] Maroto E E, Filippone S, Suárez M, Martínez-Álvarez R, de Cózar A, Cossío F P, Martín N. J Am Chem Soc, 2014, 136: 705

[22] Huisgen R. Angew Chem Int Ed, 1963, 2: 565

[23] Woodward R B, Hoffmann R. Angew Chem Int Ed, 1969, 8: 781

[24] Houk K N, Sims J, Duke R E, Strozier R W, George J K. J Am Chem Soc, 1973, 95: 7287

[25] Houk K N, Sims J, Watts C R, Luskus L J. J Am Chem Soc, 1973, 95: 7301

[26] Ruck-Braun K, Freysoldt T H E, Wierschem F. Chem Soc Rev, 2005, 34: 507

[27] Pellissier H. Tetrahedron, 2007, 63: 3235

[28] Williams R M, Fegley G J. Tetrahedron Lett, 1992, 33: 6755

[29] Mamane V, Riant O. Tetrahedron, 2001, 57: 2555

[30] Hanessian S, Yun H Y, Hou Y H, Tintelnot-Blomley M. J Org Chem, 2005, 70: 6746

[31] Rispens M T, Keller E, de Lange B, Zijlstra R W J, Feringa B L. Tetrahedron: Asymmetry, 1994, 5: 607

\section{Graphical Abstract}

Chin. J. Catal., 2015, 36: 68-77 doi: 10.1016/S1872-2067(14)60204-7

Catalytic asymmetric construction of spiro pyrrolidines with contiguous quaternary centers via 1,3-dipolar cycloaddition of azomethine ylides

Tanglin Liu, Qinghua Li, Zhaolin he, Jiawei Zhang, Chunjiang Wang*

Wuhan University; Shanghai Institute of Organic Chemistry, Chinese Academy of Sciences

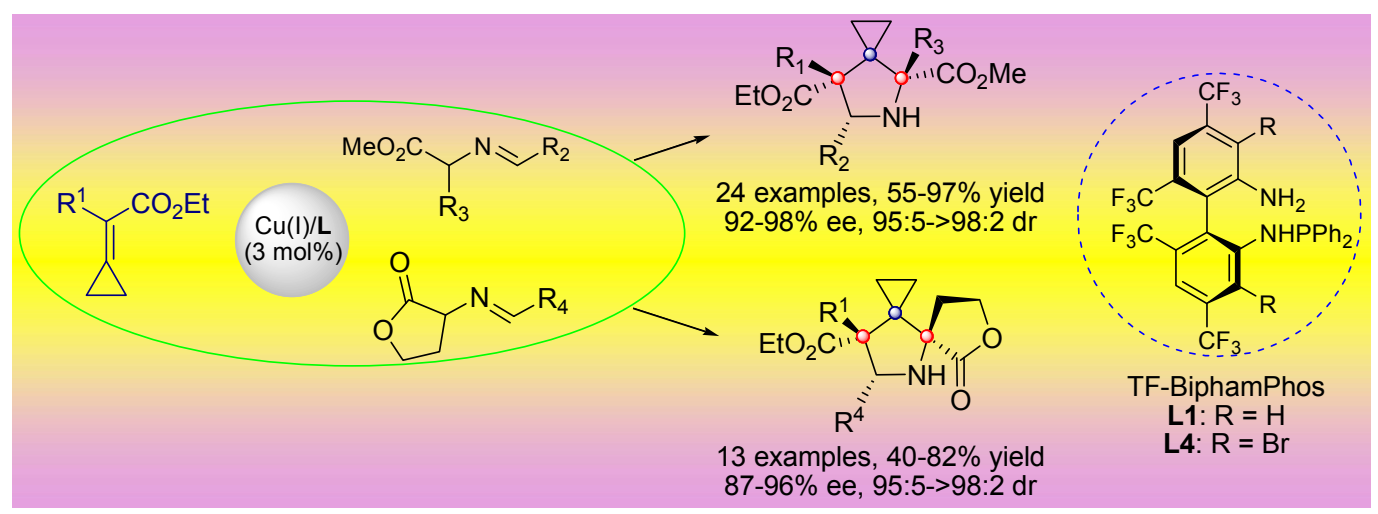

Bioactive 5-aza-spiro[2,4]heptanes with high functionality and up to three contiguous all-carbon quaternary centers were synthesized by $\mathrm{Cu}(\mathrm{I})$-catalyzed asymmetric endo-selective 1,3-dipolar cycloaddition of azomethine ylides with cyclopropylidene acetates. 
[32] Ma Z K, Wang S Y, Cooper C S, Fung A K L, Lynch J K, Plagge F, Chu D T W. Tetrahedron: Asymmetry, 1997, 8: 883

[33] Enders D, Meyer I, Runsink J, Raabe G. Tetrahedron, 1998, 54: 10733

[34] Grigg R, Thornton-Pett M, Xu J, Xu L H. Tetrahedron, 1999, 55: 13841

[35] Karlsson S, Högberg H E. Tetrahedron: Asymmetry, 2001, 12: 1975

[36] Nyerges M, Bendell D, Arany A, Hibbs D E, Coles S J, Hursthouse M B, Groundwater P W, Meth-Cohn O. Tetrahedron, 2005, 61: 3745

[37] Merino P, Tejero T, Díez-Martínez A, Gültekin Z. Eur J Org Chem, 2011: 6567

[38] Longmire J M, Wang B, Zhang X M. J Am Chem Soc, 2002, 124: 13400

[39] Gothelf A S, Gothelf K V, Hazell R G, Jörgensen K A. Angew Chem Int $E d, 2002,41: 4236$

[40] Gothelf K V, Jörgensen K A. Chem Rev, 1998, 98: 863

[41] Coldham I, Hufton R. Chem Rev, 2005, 105: 2765

[42] Husinec S, Savic V. Tetrahedron: Asymmetry, 2005, 16: 2047

[43] Najera C, Sansano J M. Angew Chem Int Ed, 2005, 44: 6272

[44] Bonin M, Chauveau A, Micouin L. Synlett, 2006: 2349

[45] Pandey G, Banerjee P, Gadre S R. Chem Rev, 2006, 106: 4484

[46] Galliford C V, Scheidt K A. Angew Chem Int Ed, 2007, 46: 8748

[47] Nair V, Suja T D. Tetrahedron, 2007, 63: 12247

[48] Pellissier H. Tetrahedron, 2007, 63: 3235

[49] Alvarez-Corral M, Munoz-Dorado M, Rodriguez-Garcia I. Chem Rev, 2008, 108: 3174

[50] Naodovic M, Yamamoto H. Chem Rev, 2008, 108: 3132

[51] Stanley L M, Sibi M P. Chem Rev, 2008, 108: 2887

[52] Engels B, Christl M. Angew Chem Int Ed, 2009, 48: 7968

[53] Najera C, Sansano J M. Org Biomol Chem, 2009, 7: 4567

[54] Chen Q A, Wang D S, Zhou Y G. Chem Commun, 2010, 46: 4043

[55] Adrio J, Carretero J C. Chem Commun, 2011, 47: 6784

[56] Xue Z Y, Liu T L, Lu Z, Huang H, Tao H Y, Wang C J. Chem Commun, 2010, 46: 1727

[57] Arai T, Mishiro A, Yokoyama N, Suzuki K, Sato H. J Am Chem Soc, 2010, 132: 5338

[58] Fukuzawa S i, Oki H. Org Lett, 2008, 10: 1747

[59] Liang G, Tong M C, Wang C J. Adv Synth Catal, 2009, 351: 3101

[60] Lopez-Perez A, Adrio J, Carretero J C. J Am Chem Soc, 2008, 130: 10084

[61] Robles-Machín R, Alonso I, Adrio J, Carretero J C. Chem Eur J, 2010, 16: 5286

[62] Chen X H, Wei Q, Luo S W, Xiao H, Gong L Z. J Am Chem Soc, 2009, 131: 13819

[63] Shi F, Tao Z L, Luo S W, Tu S J, Gong L Z. Chem Eur J, 2012, 18: 6885

[64] Cheng M N, Wang H, Gong L Z. Org Lett, 2011, 13: 2418

[65] Antonchick A P, Gerding-Reimers C, Catarinella M, Schuermann M, Preut H, Ziegler S, Rauh D, Waldmann H. Nat Chem, 2010, 2: 735

[66] Antonchick A P, Schuster H, Bruss H, Schürmann M, Preut H, Rauh D, Waldmann H. Tetrahedron, 2011, 67: 10195

[67] Awata A, Arai T. Chem Eur J, 2012, 18: 8278
[68] Sun W S, Zhu G M, Wu C Y, Li G F, Hong L, Wang R. Angew Chem Int $E d, 2013,52: 8633$

[69] Wang L, Shi X M, Dong W P, Zhu L P, Wang R. Chem Commun, 2013, 49: 3458

[70] Liu T L, He Z L, Li Q H, Tao H Y, Wang C J. Adv Synth Catal, 2011, 353: 1713

[71] Liu T L, He Z L, Tao H Y, Cai Y P, Wang C J. Chem Commun, 2011, 47: 2616

[72] Liu T L, He Z L, Wang C J. Chem Commun, 2011, 47: 9600

[73] Liu T L, Xue Z Y, Tao H Y, Wang C J. Org Biomol Chem, 2011, 9: 1980

[74] Liu T L, He Z L, Tao H Y, Wang C J. Chem Eur J, 2012, 18: 8042

[75] Pietruszka J. Chem Rev, 2003, 103: 1051

[76] Wessjohann L A, Brandt W, Thiemann T. Chem Rev, 2003, 103: 1625

[77] Baldwin J E. Chem Rev, 2003, 103: 1197

[78] Pellissier H. Tetrahedron, 2010, 66: 8341

[79] Nakamura I, Yamamoto Y. Adv Synth Catal, 2002, 344: 111

[80] Shi M, Shao L X, Lu J M, Wei Y, Mizuno K, Maeda H. Chem Rev, 2010, 110: 5883

[81] Galano A, Alvarez-Idaboy J R, Vivier-Bunge A. Theor Chem Acc, 2007, 118: 597

[82] Brandi A, Cicchi S, Cordero F M, Goti A. Chem Rev, 2003, 103: 1213

[83] Kimura Y, Atarashi S, Kawakami K, Sato K, Hayakawa I. J Med Chem, 1994, 37: 3344

[84] Yoshida T, Yamamoto Y, Orita H, Kakiuchi M, Takahashi Y, Itakura M, Kado N, Yasuda S, Kato H, Itoh Y. Chem Pharm Bull, 1996, 44: 1376

[85] Takahashi Y, Masuda N, Otsuki M, Miki M, Nishino T. Antimicrob Agents Ch, 1997, 41: 1326

[86] Jiraskova N. Curr Opin Investig Drugs, 2000, 1: 31

[87] Cianchetta G, Mannhold R, Cruciani G, Baroni M, Cecchetti V.J Med Chem, 2004, 47: 3193

[88] Park H B, Jo N H, Hong J H, Chei J H, Cho J H, Yoo K H, Oh C H. Arch Pharm, 2007, 340: 530

[89] Kim S Y, Park H B, Cho J H, Yoo K H, Oh C H. Bioorg Med Chem Lett, 2009, 19: 2558

[90] Tong M C, Li J, Tao H Y, Li Y X, Wang C J. Chem Eur J, 2011, 17: 12922

[91] Wang M Y, Wang C J, Lin Z Y. Organometallics, 2012, 31: 7870

[92] Vivanco S, Lecea B, Arrieta A, Prieto P, Morao I, Linden A, Cossío F P. J Am Chem Soc, 2000, 122; 6078

[93] Hernández-Toribio J, Arrayás R G, Carretero J C. J Am Chem Soc, 2008, 130: 16150

[94] Castelló L M, Nájera C, Sansano J M, Larrañaga O, Cózar A d, Cossío F P. Org Lett, 2013, 15: 2902

[95] Hernández-Toribio J, Gómez Arrayás R, Carretero J C. Chem Eur J, 2010, 16: 1153

[96] Kim H Y, Shih H J, Knabe W E, Oh K. Angew Chem Int Ed, 2009, 48: 7420

[97] Zhao B G, Han Z B, Ding K L. Angew Chem Int Ed, 2013, 52: 4744

\title{
亚甲胺叶立德参与的不对称 $1,3-$ 偶极环加成构建含连续 季碳中心的螺四氢吡咯衍生物
}

\author{
刘堂林 ${ }^{\mathrm{a}}$, 李清华 ${ }^{\mathrm{a}}$, 何照林 ${ }^{\mathrm{a}}$, 张佳伟 ${ }^{\mathrm{a}}$, 王春江 ${ }^{\mathrm{a}, \mathrm{b}, *}$

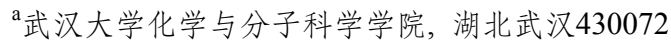

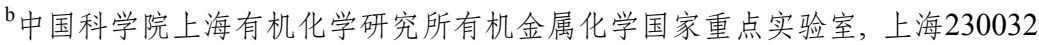


摘要: $\mathrm{Cu}(\mathrm{I})$ 催化的亚甲胺叶立德和亚环丙基乙酸乙酯参与的不对称endo-1,3-偶极环加成反应, 高效构建了多官能化、含有多个连 续季碳中心的5-氮杂-[2,4]庚烷化合物. 此反应具有广泛的底物适用性, $\alpha$-取代的和 $\alpha$-非取代的亚甲胺叶立德和亚环丙基乙酸乙酯 都能很好的参与反应, 并以很高的产率、优秀的非对映选择性(95:5-> 98:2 d.r ) 和对映选择性( $87 \%-98 \%$ ee)生成相应的在 2,3 , 位上 含有连续季碳中心的螺四氢吡咯化合物.

关键词: 不对称催化; 季碳中心; 1,3-偶极环加成; 亚甲胺叶立德; 亚环丙基乙酸乙酯; 5-氮杂-[2,4]庆烷

收稿日期: 2014-06-26. 接受日期: 2014-07-22. 出版日期: 2015-01-20.

*通讯联系人. 电话/传真: (027)68754067; 电子信箱: cjwang@whu.edu.cn

基金来源: 国家重点基础研究发展计划(973计划, 2011CB808600); 国家自然科学基金(21172176, 21372180); 湖北省高等学校科 研基金资助项目(ZRZ0273); 中央高校基本科研业务费专项资金; 教育部博士学术新人奖(5052011203011).

本文的英文电子版由Elsevier出版社在ScienceDirect上出版(http://www.sciencedirect.com/science/journal/18722067).

\section{1. 前言}

天然产物以及药物分子中全碳季碳中心的存在, 增 加了这些分子的合成难度. 在过去的几十年中, 报道了 多种构建手性的全碳季碳中心的方法 ${ }^{[1-7]}$. 但是通过简 单的一步不对称转化构建连续的全碳季碳中心仍然是 “在天然产物合成领域一个艰巨的挑战” ${ }^{[8]}$. 最近 ${ }^{[9-11]}$, 有关连续季碳中心的构建方法主要有: $\mathrm{Pd}$ 催化的去 $\mathrm{CO}_{2}$ 不对称烯丙基烷基化反应(Pd-DAAA) ${ }^{[12,13]}$, Pd催化的5乙烯基噁唑啉酮与三取代烯酮的不对称 [3+2]环加成反 应 $^{[14]}$, 连续的Michael加成反应 ${ }^{[15]}$ 以及3-溴代氧化吲哚与 3-取代吲哚的烷基化反应 ${ }^{[16]}$ 等.

氮杂环的四氢吡咯类化合物是许多天然产物、药物 分子以及一些具有生理活性分子中重要的结构单元, 且 作为重要的分子骨架在有机合成中占据重要的地 位 ${ }^{[17,18]}$. 同时, 近几年手性的四氢吡咯衍生物还用作有 机小分子催化剂 ${ }^{[19-21]}$. 而构建五元杂环最有效的方法就 是各种1,3-偶极子和缺电子的烯烃或炔烃的 1,3 -偶极环 加成反应 ${ }^{[22-27]}$. 虽然在手性辅剂诱导的 1,3 -偶极环加成 反应中, 金属稳定的亚甲胺叶立德是构建手性四氢吡咯 的一个很好的1,3-偶极子 ${ }^{[28-37]}$, 但是对于催化量的手性 催化剂催化的亚甲胺叶立德与缺电子烯烃的不对称 $1,3-$ 偶极环加成反应, 至 2002 年才由 Zhang 课题组 ${ }^{[38]}$ 和 Jörgensen 课 题 组 ${ }^{[39]}$ 分别用 $\operatorname{Ag}(\mathrm{I}) / \mathrm{xylyl}-\mathrm{FAP}$ 和 $\mathrm{Zn}(\mathrm{II}) / \mathrm{bisoxazoline}$ 催化剂实现. 自此之后, 亚甲胺叶立 德与缺电子烯烃之间催化不对称 1,3 -偶极环加成反应受 到了广泛的关注, 并合成了一系列多官能化的手性四氢 吡咯化合物 ${ }^{[40-55]}$. 对于季碳中心, 特别是螺环的季碳中 心的构建也有报道 ${ }^{[56-61]}$. 最近, Gong 课题组 ${ }^{[62-64]}$, Waldmann课题组 ${ }^{[65,66]}$, Arai等 ${ }^{[67]}$, Wang 课题组 ${ }^{[68,69]}$ 以及 我们课题组 ${ }^{[70-74]}$ 均通过亚甲胺叶立德与三取代的缺电 子烯烃的催化不对称 1,3-偶极环加成反应, 来合成含有 手性螺环季碳中心四氢吡咯化合物; 但是, 通过该反应
来构建含有连续季碳中心的手性四氢吡咯化合物, 到目 前为止尚未见报道.

在许多的天然产物以及药物分子 (如萜类化合物和 甾类化合物) 中, 环丙烷结构都表现出重要的生理活 性 ${ }^{[75-77]}$. 在过去的几十年里, 亚甲基环丙烷(MCP)一直 是有机合成中重要的中间体 ${ }^{[78,79]}$, 在金属催化的反应中, $\mathrm{MCP}$ 由于三元环的环张力而使得它们一般经过开环反 应后作为碳三合成子参与反应 ${ }^{[80,81]}$. 同样地, 在不开环 的情况下, MCP能作为亲偶极体与硝酮、腈氧化物、叠 氮、重氮化合物、腈叶立德以及肜等发生1,3-偶极环加 成反应以及Diels-Alder反应等 ${ }^{[82]}$.

我们已经报道了 $\mathrm{Cu}(\mathrm{I}) / \mathrm{TF}-\mathrm{BiphamPhos}$ 催化的亚甲 胺叶立德与亚环丙基乙酸乙酯的不对称 1,3 -偶极环加成 反应, 高效地构建了螺 [环丙烷-3,3'-四氢吡咯]类化合物, 且具有非常高的endo选择性和对映选择性(表 1$)^{[71]}$. 通 过螺碳原子将这两个具有生理活性的部分连接在一起 的螺[环丙烷-3,3'-四氢吡咯], 也就是5-氮杂-螺[2,4]庚烷 在一些抗菌试剂中起着重要的作用. 现已证明, 5-氮杂螺 $[2,4]$ 庚烷结构能够显著提高碳青霉烯类似物, 取代的 噁唑烷酮类以及喹诺酮类抗生素对革兰氏阳性和革兰 氏阴性细菌的作用 ${ }^{[83-89]}$.

为了深入研究此反应, 本文通过 $\mathrm{Cu}(\mathrm{I}) / \mathrm{TF}-\mathrm{Bipham}-$ Phos催化的各种 $\alpha$ 取代的及 $\alpha$ 未取代的亚胺酯和各种 $\alpha$ 取 代的亚环丙基乙酸乙酯的不对称1,3-偶极环加成反应, 高效地构建含有高达三个连续季碳中心的多官能化的 手性5-氮杂-螺[2,4]庚烷化合物(图式1).

\section{2. 实验部分}

$\mathrm{Cu}\left(\mathrm{CH}_{3} \mathrm{CN}\right)_{4} \mathrm{BF}_{4} /(S)$-TF-BiphamPhos 催化的亚甲胺 叶立德与亚环丙基乙酸乙酯的不对称 1,3 -偶极环加成反 应的一般步骤如下. $\mathrm{N}_{2}$ 保护下, 在 $25 \mathrm{~mL}$ 反应管中, 将 (S)-TF-BiphamPhos $(0.0072 \mathrm{mmol})$ 与 $\mathrm{Cu}\left(\mathrm{CH}_{3} \mathrm{CN}\right)_{4} \mathrm{BF}_{4}$ $(2.0 \mathrm{mg}, 0.006 \mathrm{mmol})$ 溶于 $2 \mathrm{~mL}$ 二氯甲烷中, 并在室温下 
搅拌 $1 \mathrm{~h}$. 然后依次加入亚胺酯 $(0.40 \mathrm{mmol})$, 三乙胺 $(0.03$ $\mathrm{mmol}$ )和亚环丙基乙酸乙酯 $(0.20 \mathrm{mmol})$, 以 TLC监测反 应. 反应完成后, 硅藻土过滤, 将滤液旋干得粗产物, 通 过 ${ }^{1} \mathrm{H}$ NMR来确定d.r. 值, 柱层析纯化得到环加成产物, 产物的ee值由HPLC测定.

\section{3. 结果与讨论}

\section{1. $\mathrm{Cu}(\mathrm{I}) / \mathrm{TF}-$ BiphamPhos催化的 $\alpha$ 取代的亚甲胺叶立 德 2 与亚环丙基乙酸乙酯 $1 a$ 的 $[3+2]$ 环加成反应}

基于 $\alpha$ 未取代的亚胺酯与亚环丙基乙酸乙酯 $1 \mathbf{a}$ 之间 良好的反应结果 ${ }^{[71]}$, 我们将 $\alpha$ 取代的亚胺酯作为 1,3 -偶极 子前体参与反应. 反应时, $\alpha$ 取代的亚胺酯由于亚胺与羧 酸酯之间的亚甲基的酸性减弱使得它们的反应活性降 低, 导致它们作为偶极子参与反应的困难更大, 更具有 挑战性. 尽管含有手性季碳中心的四氢吡咯化合物具有 重要的作用, 但是 $\alpha$ 取代的亚胺酯参与催化不对称 $1,3-$-偶 极环加成的例子并不多. 令人欣慰的是, 在此 $\mathrm{Cu}(\mathrm{I}) /$ TF-BiphamPhos (L1)催化的亚甲胺叶立德与亚环丙基乙 酸乙酯 $1 \mathbf{a}$ 的不对称1,3-偶极环加成反应中, $\alpha$ 取代的亚胺 酯也能很好地参与反应, 如表2所示. 在最佳反应条件 下, 由 $\alpha$ 取代的氨基酸, 如丙氨酸、2-氨基丁酸、亮氨酸、 苯甘氨酸以及2-氨基苯丙酸衍生的 $\alpha$ 取代亚胺酯都能参 与反应, 且能以很高的非对映选择性和对映选择性获得 含有两个(其中一个是手性的季碳中心)的环加成产物.

\section{2. 亚甲胺叶立德 $2 a$ 与 $\alpha$ 取代的亚环丙基乙酸乙酯 1 的} $[3+2]$ 环加成反应

为了进一步拓展反应底物的适用范围, 我们尝试具 有较大空间位阻的亲偶极体, 因此, 将 $\alpha$ 取代的亚环丙基 乙酸乙酯作为亲偶极体用于 $\mathrm{Cu}(\mathrm{I}) / \mathrm{TF}-$ BiphamPhos (L1) 催化的亚甲胺叶立德参与的不对称1,3-偶极环加成反应 中, 从而在螺 [环丙烷-四氢吡咯]的3位和7位上构建两个 连续的季碳中心. 如表3所示, 在最佳的反应条件下, 我 们成功地将亲偶极体的范围拓展到 $\alpha$ 取代的亚环丙基乙 酸乙酯. 亚环丙基乙酸乙酯的 $\alpha$ 位上有烷基取代基[如甲 基(1b)、乙基(1c)、正丙基(1d)和苠基(1e)]以及芳基取代 基[苯基(1f)]等在 $\mathrm{Cu}(\mathrm{I}) / \mathrm{TF}-\mathrm{BiphamPhos}(\mathbf{L 1})$ 的催化下, 都 可以与亚胺酯(2a)发生不对称1,3-偶极环加成反应, 且目 标产物的产率、非对映选择性和对映选择性都比较高(> 98:2 d.r., 92\%-96\% ee). 这是第一例关于四取代的缺电 子烯烃与亚甲胺叶立德的催化不对称 1,3 -偶极环加成反 应. 通过单晶衍射测定 $\mathbf{3 c a}$ 的对甲苯磺酰化产物 $\mathbf{4}$ 的绝对 构型, 环加成产物的绝对构型确定为 $(4 R, 6 R, 7 R)$.
3.3. $\mathrm{Cu}(\mathrm{I}) / \mathrm{TF}-\mathrm{BiphamPhos}$ 催化的高丝氨酸内酯衍生 的环状亚胺 5 与亚环丙基乙酸乙酯 $1 \mathrm{a}$ 的 $[3+2]$ 环加成反应

为了继续深入拓展 $\mathrm{Cu}(\mathrm{I}) / \mathrm{TF}-\mathrm{BiphamPhos}$ 催化的亚 甲胺叶立德与亚环丙基乙酸乙酯的不对称 1,3 -偶极环加 成构建螺 [环丙烷-3,3'-四氢吡咯]反应底物的适用范围, 我们还将由高丝氨酸内酯衍生的环状亚胺作为偶极子, 以期在手性四氢吡咯环上的 2 位和 3 位上构建两个连续 的季碳中心, 且获得同时含有环丙烷、四氢吡咯和丁内 酯结构的三环化合物.

在上文最佳反应条件 $\left(3 \mathrm{~mol} \%\right.$ 的 $\mathrm{Cu}\left(\mathrm{CH}_{3} \mathrm{CN}\right)_{4} \mathrm{BF}_{4} /$ TF-BiphamPhos (L1) 为催化剂, $15 \mathrm{~mol} \%$ 的三乙胺为碱, DCM为溶剂, $\left.-20{ }^{\circ} \mathrm{C}\right)$ 下, 由高丝氨酸内酯和苯甲醛合成 的环状亚胺 $\mathbf{5 e}$ 与亚环丙基乙酸乙酯 $1 \mathbf{a}$ 发生 $[3+2]$ 环加成 反应, 以中等收率(78\%)和 $82 \%$ 的ee获得了目标产物. 因 此, 我们需要重新优化反应条件, 结果如表4所示. 在室 温时, $3 \mathrm{~mol} \%$ 的 $\mathrm{Cu}\left(\mathrm{CH}_{3} \mathrm{CN}\right)_{4} \mathrm{BF}_{4} / \mathrm{TF}-\mathrm{BiphamPhos}(\mathbf{L} 4)$ 的 催化下反应结果最好(6ae, 产率 $80 \%$, ee值 $95 \%$ ).

在重新确定的最佳反应条件下, 我们拓展了环状亚 胺的适用范围(表5). 亚环丙基乙酸乙酯 $1 \mathbf{a}$ 能够与各种 取代的环状亚胺发生 $[3+2]$ 环加成反应且目标产物的产 率(40\%-82\%)、非对映选择性(> 98:2的d.r. 值)和对映选 择性 $(87 \%-96 \%)$ 都比较高. 螺四氢吡咯的10位上的取代 基可以是芳基 [如给电子基团(表 5 , 实验 1-4, 6aa-6ad)、 电中性基团(表 5 , 实验 $5, \mathbf{6 a e}$ )和拉电子基团(表 5 , 实验 6-9, 6af-6ai)] 以及杂环的芳基[如2-呋喃(6ak)和2-噻吩 (6al)]. 1-萗醛衍生的亚胺酯也能反应并得到 $70 \%$ 的收率 以及 $90 \%$ ee. 但是烷基取代的环状亚胺在此反应中的活 性太低, 没有获得相应的环加成产物. 螺环化合物的绝 对构型为 $(4 R, 10 S, 11 R)$.

3.4. 构建含有三个连续季碳中心的螺四氢吡咯化合物 的催化不对称 $1,3-$ 偶极环加成反应

最后, 我们尝试构建含有三个连续季碳中心, 其中 两个是手性季碳中心的手性螺[环丙烷-3,3'-四氢吡咯]化 合物. 在 $\mathrm{Cu}\left(\mathrm{CH}_{3} \mathrm{CN}\right)_{4} \mathrm{BF}_{4} / \mathrm{TF}-\mathrm{BiphamPhos}(\mathbf{L} \mathbf{1}$ 或 L4) 的催 化下, $\alpha$ 取代的亚胺酯 $\mathbf{2 n}$ 和环状亚胺 $\mathbf{5 e}$ 分别与 $\alpha$ 苠基取代 亚环丙基乙酸乙酯 $1 \mathbf{e}$ 发生[3+2]环加成反应(图式2), 可 以获得相应的目标产物, 且反应的非对映选择性和对映 选择性(ee值: 7, 96\%; 8, 93\%)都很高, 尽管产率中等. 这 是首次通过催化不对称 1,3 -偶极环加成反应构建含有三 个连续季碳中心的四氢吡咯衍生物.

\section{5. 可能的反应过渡态}

根据反应产物的绝对构型以及我们对金属 
/TF-BiphamPhos催化体系在1,3-偶极环加成反应作用的 理解和密度泛函 (DFT) 计算 ${ }^{[90,91]}$, 我们提出了 Michael/Mannich 的分步过程及其可能的过渡态模

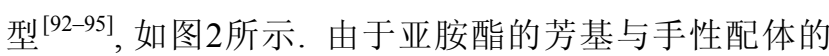
磷原子上的芳基具有很大的空间位阻作用, 使得新形成 的亚甲胺叶立德与金属中心只能以图中所示的最佳方 式配位, 为了减少反应的阻力以及提高反应的选择性, 随后亚环丙基乙酸乙酯作为亲偶极体只能进攻络合物 中空间位阻比较小的一面, 即 $\mathrm{C}=\mathrm{N}$ 的 $S i$ 面, 从而获得 $e n d o$ 构型的环加成产物. 亲偶极体中的 $\mathrm{C}=\mathrm{O}$ 与配体 TF-BiphamPhos中的 $\mathrm{NH}_{2}$ 可能形成氢键, 这样也能更好 的稳定反应的过渡态 ${ }^{[96,97]}$.

\section{4. 结论}

发现了一个高效、简单快捷的方法构建手性的endo 构型的5-氮杂-螺 $[2,4]$ 庚烷衍生物. 即铜(I)催化的各种 $\alpha$ 取代的亚甲胺叶立德与 $\alpha$ 取代和无取代的亚环丙基乙酸 乙酯的不对称 1,3 -偶极环加成反应. 该方法为构建含有 多达三个连续季碳中心的多取代 5-氮杂-螺 [2,4]庚烷提 供了简单直接的方法, 且可以高立体选择性的获得同时 含有环丙烷、四氢吡咯和丁内酯结构的三环两螺原子结 构的手性四氢吡咯化合物.

致谢 感谢武汉大学的李桦教授在单晶数据测试和解析上 的帮助. 